\begin{tabular}{|c|l|}
\hline Title & Source model of the great 2011 Tohoku earthquake estimated from tsunami waveforms and crustal deformation data \\
\hline Author(s) & Gusman, A ditya Riadi; Tanioka, Y uichiro; Sakai, Shinichi; Tsushima, Hiroaki \\
\hline Citation & $\begin{array}{l}\text { Earth and Planetary Science Letters, 341-344, 234.242 } \\
\text { https://doi.org/L0.1016/.epsl.2012.06.006 }\end{array}$ \\
\hline Issue Date & 2012-08 \\
\hline Doc URL & http://hdl.handle.net/2115/50289 \\
\hline Type & article (author version) \\
\hline Additional Information & There are other files related to this item in HUSCAP. Check the above URL. \\
\hline File Information & EPSL341-344_234_242.pdf \\
\hline
\end{tabular}

Instructions for use 


\section{Source model of the great 2011 Tohoku earthquake estimated from tsunami waveforms and crustal deformation data}

8 Abstract tsunami waveforms, GPS data, and seafloor crustal deformation data. The major slip region extends all the way to the trench, and the large slip area extends $300 \mathrm{~km}$ long and $160 \mathrm{~km}$ wide. The largest slip of $44 \mathrm{~m}$ is located up-dip of the hypocenter. The large slip amount, about $41 \mathrm{~m}$, ruptured the plate interface near the trench. The seismic moment calculated from the estimated slip distribution is $5.5 \times 10^{22} \mathrm{~N} \mathrm{~m}(\mathrm{Mw} 9.1)$. The large tsunami due to the 2011 Tohoku earthquake is generated from those large slip areas near the trench. The additional uplift at the sedimentary wedge as suggested for the 1896 Sanriku earthquake may have occurred during the 2011 Tohoku earthquake, too.

Keywords: tsunami waveforms, GPS data, seafloor crustal deformation data, the 2011 Tohoku earthquake

\section{Introduction}

The great 2011 Tohoku earthquake occurred on 11 March 2011 at 5:46:18 UTC with epicenter at $38.104^{\circ} \mathrm{N}$ and $142.861^{\circ} \mathrm{E}$ off the east coast of Tohoku and about $130 \mathrm{~km}$ from Sendai, Japan, according to the Japan Meteorological Agency (JMA). The largest foreshock 
occurred at 2:45:13 UTC on 9 March 2011 with Mw 7.3 (JMA) at $38.328^{\circ} \mathrm{N}$ and $143.28^{\circ} \mathrm{E}$.

The largest aftershock with Mw 7.7 occurred approximately 28 min after the mainshock (6:15:34 UTC) at $36.108^{\circ} \mathrm{N}$ and $141.265^{\circ} \mathrm{E}$ (JMA). Approximately $39 \mathrm{~min}$ after the mainshock (6:25:44 UTC) a large extensional faulting (Mw 7.5) occurred in the outer-rise at $37.837^{\circ} \mathrm{N}$ and $144.894^{\circ} \mathrm{E}$ (JMA). Fig. 1 is a map showing the location of the mainshock, foreshocks and aftershocks.

The Global Centroid Moment Tensor (GCMT) solution estimated that the 2011 Tohoku earthquake released seismic moment of $5.3 \times 10^{22} \mathrm{~N} \mathrm{~m}(\mathrm{Mw} 9.1)$. The dip angle at the centroid is ranging from $10^{\circ}$ to $14^{\circ}$ (GCMT, WCMT, and USGS). Seismic reflection and refraction images suggest that the dip angle near the trench is about $3^{\circ}$ (Tsuji et al., 2011; Ito et al., 2011). A rupture model of the 2011 earthquake by Ammon et al. (2011) included a low initial rupture speed $(1.5 \mathrm{~km} / \mathrm{s})$ near the hypocenter and an increase in speed $(2.5 \mathrm{~km} / \mathrm{s})$ at distances larger than $100 \mathrm{~km}$ from the hypocenter. Lay et al. (2011) explored the possibility of large near-trench slip during the great 2011 Tohoku earthquake by teleseismic P-waves inversion and estimated large slip $(60 \mathrm{~m})$ at shallow depth near the trench. Large slip near the trench was estimated using tsunami waveforms by previous studies (Fujii et al., 2011; Maeda et al., 2011; Saito et al., 2011). Total seismic moment estimates for the 2011 earthquake from previous studies using W-phase, teleseismic waveform, strong motion, and tsunami waveform are $3.9 \times 10^{22} \mathrm{~N} \mathrm{~m}(\mathrm{Mw} 9.0)$ (Ammon et al., 2011), $4.3 \times 10^{22} \mathrm{~N} \mathrm{~m}(\mathrm{Mw} 9.1)$ (Yoshida et al., 2011), $3.4 \times 10^{22} \mathrm{~N} \mathrm{~m}$ (Mw 9.0) (Yoshida et al., 2011), and $3.8 \times 10^{22} \mathrm{~N} \mathrm{~m}$ (Mw 9.0) (Fujii et al., 2011), respectively.

The 2011 Tohoku earthquake occurred within the Japan Trench subduction zone where the Pacific plate subducts beneath the Okhotsk plate. A large tsunami was generated by the 2011 Tohoku megathrust earthquake and devastated the coastal area along the north east coast of Honshu. The National Police Agency of Japan has confirmed casualties of about 
$49 \quad 16,000$ deaths, 3,000 people missing, and 6,000 injured

50 (http://www.npa.go.jp/archive/keibi/biki/higaijokyo_e.pdf). The tsunami was observed by tide

51 gauges, pressure gauges, GPS buoys, and Deep-ocean Assessment and Reporting of

52 Tsunamis (DART) buoys that are located offshore and across the Pacific Ocean. The 2011

53 Tohoku Earthquake Tsunami Joint Survey Group measured tsunami run-up at more than

545200 locations along the east coast of Tohoku area, maximum run-up heights greater than 10

$55 \mathrm{~m}$ are distributed along $500 \mathrm{~km}$ of coast (Mori et al., 2012). Tsunami height exceeds $20 \mathrm{~m}$ at

56 heads of $\mathrm{V}$-shaped bays and apexes of peninsulas, and exceptional tsunami heights of over 35

57 m was measured at a small valley, Aneyoshi, on Omoe peninsula (Shimozono et al., 2012).

58 Fritz et al., (2012) measured a maximum tsunami outflow currents of $11 \mathrm{~m} / \mathrm{s}$ and an average water level increase of $1 \mathrm{~m} /$ minute within 12 minutes of flooding from survivor videos at Kesennuma Bay using LiDAR.

Old documents show that a large earthquake occurred off the coast of Sendai on 13 July 869. Tsunami deposit studies revealed the tsunami generated by the 869 Jogan earthquake inundated and damaged entire Sendai plain up to more than $4 \mathrm{~km}$ inland (Minoura et al., 2001; Namegaya et al., 2010). According to historical records, the 1611 Keicho Sanriku earthquake also generated large tsunami and inundated Sendai plain up to $4 \mathrm{~km}$ inland (Tsuji, 2003). To the north of the 2011 rupture area, two great earthquakes occurred off the coast of Sanriku; a thrust earthquake ( $\mathrm{Mw} 8.5)$ that is identified as a tsunami earthquake event occurred in 1896 (Kanamori, 1972; Tanioka and Satake, 1996a); and an outer-rise earthquake (Mw 8.4) that occurred within the oceanic plate near the Japan Trench in 1933 (Kanamori, 1971). Both of the Sanriku earthquakes generated large tsunamis that devastated the Sanriku coastal area (Kanamori, 1972; Tanioka and Satake, 1996a). The 1978 (Mw 7.6) and the 2005 (Mw 7.2) Off-Miyagi earthquakes occurred within the rupture area of the 2011 earthquake (Yamanaka and Kikuchi, 2004; Miura et al., 2006). 
(GEONET) on main islands of Japan that is maintained by Geospatial Information Authority of Japan (GSI) (Sagiya et al., 2000) detected coseismic and postseismic displacements due to the 2011 earthquake (Ozawa et al., 2011). Crustal movement monitoring at underwater reference stations off the east coast of Tohoku reveals that coseismic displacement there due to the earthquake is large up to $24 \mathrm{~m}$ of horizontal motion (Sato et al., 2011).

Previous studies indicated that large slip beneath a sedimentary wedge near the trench caused large horizontal movement of backstop and that generated large additional uplift of the sediment (Seno, 2000; Tanioka and Seno, 2001; Seno and Hirata, 2007). Those studies indicated that this additional uplift of sediment near a trench has large effect on tsunami generation. The uplift of sediments near the trench can be calculated from the horizontal movement of the backstop (Tanioka and Seno, 2001). Another tsunami generation mechanism that is associated with horizontal displacement of the sloping bathymetry near the trench was suggested by Tanioka and Satake (1996b).

The slip distribution of the 2011 earthquake inferred from GPS data at inland stations has a major slip region that is centered near the epicenter (Ozawa et al., 2011), whereas the slip distributions of the 2011 earthquake inferred from tsunami waveforms have the largest slip amounts at shallow depth near the trench (Fujii et al., 2011; Maeda et al., 2011; Saito et al., 2011). The tsunami waveforms and GPS data at these stations are important for developing a deeper understanding of the generation of a tsunami by a megathrust earthquake. The data at offshore stations provide strong constraints on the slip distribution of the earthquake. The tsunami waveforms observed at stations surrounding the source area and GPS data observed across Japan constrain the overall rupture area. In this paper we estimate the source model of the 2011 tsunami using tsunami waveforms, GPS data on main islands of Japan and seafloor crustal deformation data. 


\section{Observation data}

\subsection{Tsunami waveform data}

To estimate slip distribution of the earthquake we use tsunami waveforms at 17 stations. These stations include 5 DART buoys in the Pacific Ocean (DART21401, DART21413, DART21418, DART21419 and DART52402), 2 tide gauges in Hokkaido Prefecture (Erimo and Mori), 1 tide gauge in Katsuura, Chiba Prefecture, 1 tide gauge in Ito, Shizuoka Prefecture, 2 bottom-pressure gauges off the coast of Tokachi (KPG1 and KPG2), 2 bottom-pressure gauges off the coast of Iwate Prefecture (TM1 and TM2), and 4 GPS buoys off the coast of Iwate, Miyagi, and Fukushima Prefectures (GPSB802, GPSB803, GPSB804 and GPSB806).

The National Oceanic and Atmospheric Administration (NOAA) operates the DART buoys. The Ministry of Land, Infrastructure, Transport, and Tourism (MLIT) operates the tide gauges in Mori, Hokkaido. The JMA operates the tide gauge in Erimo, Hokkaido. The GSI operates the tide gauges in Katsuura and Ito. The bottom pressure gauges of TM1 and TM2 are operated by University of Tokyo and Tohoku University, KPG1 and KPG2 are operated by the Japan Agency for Marine-Earth Science and Technology (JAMSTEC). MLIT and the Port and Airport Research Institute (PARI) operate the GPS buoys. The details of the stations are listed in Table $\mathbf{S 1}$ and plotted on the map in Fig. 2.

These records include ocean tides, which should be removed to get the tsunami waveforms. The ocean tides are approximated by fitting a polynomial function, and are removed from the original records. The records from the 4 bottom-pressure sensors (KPG1, KPG2, TM1 and TM2) also contain high frequency waves; hence the tsunami waveforms are approximated by calculating the moving average of the record. 
Crustal deformation due to the 2011 Tohoku earthquake was observed by the GPS

GEONET that is operated by the GSI. The Advanced Rapid Imaging and Analysis (ARIA) team at Jet Propulsion Laboratory (JPL) and California Institute of Technology (Caltech) estimated coseismic displacements due to the earthquake from 5 minutes interval of kinematic solutions of the GPS data. We use the coseismic displacements data (version 0.3 , ftp://sideshow.jpl.nasa.gov/pub/usrs/ARIA/ARIA_coseismic_offsets.v0.3.table) estimated by the ARIA team at 1230 GPS stations in Japan to help estimate the slip distribution of the 2011 Tohoku earthquake. 
147 Rake angles of $45^{\circ}$ and $135^{\circ}$ are used for each subfault to estimate the slip direction of each 148 subfault (within the range between $45^{\circ}$ and $135^{\circ}$ ).

The initial sea surface deformation is assumed to be the same as the ocean bottom

150

151

152 deformation if the spatial wavelength of the ocean bottom deformation is much larger than the ocean depth (Satake, 2002). This assumption cannot be applied to obtain sea surface deformation from the ocean bottom deformation that is induced by faulting of a very shallow fault near a trench, because the deformation near the trench has steep slope with spatial wavelength that is smaller than ocean depth. Therefore, the initial sea surface deformation for subfaults near the trench (A and B subfaults) (Fig. 1) is computed from the coseismic vertical deformation on the ocean bottom using Kajiura (1963) formula. For the other subfaults, it is assumed to be equal to the coseismic vertical deformation. The coseismic horizontal and vertical deformations on the ocean bottom are computed for each subfault with unit amount of slip using Okada (1985) formula.

\subsection{Tsunami numerical simulation}

The bathymetry data sets used for tsunami simulation are based upon the General Bathymetric Chart of the Oceans (GEBCO) 30 arc-second data set and the Japan Hydrographic Association's M7001 and M7006 bathymetric contour data sets. The computation area ranges from $130^{\circ}$ to $160^{\circ} \mathrm{E}$ and from $10^{\circ}$ to $50^{\circ} \mathrm{N}$. We use different grid systems with grid sizes of 90 arc-seconds, 30 arc-seconds, and 10 arc-seconds to compute the tsunami. The finest grids are used for the coastal area around the Erimo, Mori, Katsuura, and Ito tide gauge stations.

Synthetic tsunami waveforms generated from all subfaults at the stations were numerically computed by solving the linear shallow water equations with spherical coordinate system (Johnson, 1998). We used a tsunami model that has been developed and 
used in tsunami waveform inversion studies (i.e. Fujii and Satake, 2008; Tanioka et al., 2008; Gusman et al., 2010; Fujii et al., 2011). Tsunami in the deep ocean is not affected by coastal effects and simulation of the tsunami using the linear shallow water equations is widely accepted (Synolakis et al., 2008). While the nonlinearity becomes important around coastal tide gauge stations, Fujii et al. (2011) confirmed by comparing the nonlinear and linear computations that they produce similar arrival times and initial slopes. The sea level observation instruments used different sampling rates, so the tsunami waveforms are resampled at 15 seconds interval and the synthetic tsunami waveforms are also resampled at 15 seconds interval.

\subsection{Joint inversion}

We estimate a slip distribution by a joint inversion using the tsunami waveforms and crustal deformation data. A green's function for the joint inversion is made from the synthetic of tsunami waveforms and crustal deformation using the fault parameters. The number of tsunami waveforms data points that we used is 2989 , while the number of crustal deformation data points at the 1235 stations is 3705 .

We used non-negative least square method (Lawson and Hanson, 1974) and include a spatial smoothness constraint to estimate the slip distribution of the earthquake. The optimal value of smoothing factor was selected to minimize Akaike's Bayesian information criterion (ABIC) (Akaike, 1980). For more details of our inversion method, see Gusman et al. (2010). A "delete-half" Jackknife resample is extracted from the original data by deleting half the number of data points. The standard error of the slip distribution is calculated using 50 models that are estimated from the "delete-half" Jackknife resamples (Tichelaar and Ruff, 1989).

\section{Results}


The maximum slip amount is estimated to be $44 \mathrm{~m}$ and the major slip region is located up-dip of the hypocenter with dimensions of roughly $300 \mathrm{~km}$ length and $160 \mathrm{~km}$ width (Fig. 3a). The earthquake ruptured the plate interface from the hypocenter all the way to the trench with large slip amount, about $41 \mathrm{~m}$, near the trench. These results are consistent with results from inversion analysis based on dispersive tsunami simulation by Saito et al. (2011). The seismic moment calculated from the slip distribution is $5.5 \times 10^{22} \mathrm{~N} \mathrm{~m}(\mathrm{Mw} 9.1)$ by assuming the rigidity of $4 \times 10^{10} \mathrm{~N} \mathrm{~m}^{-2}$. The estimated average rake angle from the slip distribution is $88^{\circ}$ (Fig. 4a), which is equal to the rake angle at the centroid (GCMT). The slip distribution generated sea surface deformation with a maximum water level of about $9 \mathrm{~m}$ above mean sea level (Fig. 3c).

The calculated horizontal and vertical displacements at GPS stations and at seafloor reference points resemble the observations. Comparisons between the calculated and the observed horizontal and vertical displacements are shown in Fig. 5a. We compare the simulated tsunami waveforms from the estimated slip distribution with the observed tsunami waveforms at sea level observation stations in Fig. 6. Overall, observed tsunami waveforms are well explained by simulated tsunami waveforms.

\section{Discussion}

The main difference between the slip distributions of the 2011 earthquake estimated from GPS data (i.e. Ozawa et al., 2011) and those estimated from tsunami waveforms (i.e. Fujii et al., 2011; Maeda et al., 2011; Saito et al., 2011) is the location of the largest slip amount. The slip distribution estimated from GPS data concentrated near the epicenter whereas that estimated from tsunami waveforms has large slip near the trench. By using tsunami waveforms, GPS data and seafloor crustal deformation data in a joint inversion, a more accurate slip distribution of the 2011 earthquake can be estimated. In this study, the slip 
distribution of the 2011 earthquake estimated from tsunami waveforms and crustal deformation data has large slip near the trench similar to those estimated by previous studies

221 (Fujii et al., 2011; Maeda et al., 2011; Saito et al., 2011), and the slip distribution can explain well the tsunami waveforms and crustal deformation data.

Because Tanioka and Seno (2001) suggested that the additional uplift along the unconsolidated sedimentary wedge near the trench generated the additional tsunami for the 1896 Sanriku tsunami, we also need to test that the observed tsunami waveforms can be explained by the additional uplift near the trench. In this study, the calculation of the additional uplift is following the Model A in Tanioka and Seno (2001). The uplift of the sediments, $u_{s}$, is represented by $u_{s}=u_{h} \tan \theta$ where $u_{h}$ is the horizontal movement due to earthquake, and $\theta$ is the dip angle of the slope. A seismic profile after the 2011 earthquake provided by JAMSTEC shows a large bathymetric change near the trench that has a width of $1.5 \mathrm{~km}$. To calculate additional uplift, we assume that the dip angle of the backstop slope $(\theta)$ is $50^{\circ}$, which is the same as that of Tanioka and Seno (2001), and the width of uplift area is $1.5 \mathrm{~km}$. The horizontal movement $\left(u_{h}\right)$ is computed for each subfault "A" with unit amount of slip using Okada (1985) formula. The sea surface deformation of the additional uplift is calculated by the Kajiura (1963) formula because the width of the additional uplift is $1.5 \mathrm{~km}$, which is smaller than the ocean depth. Then a slip distribution is estimated by joint inversion using green's function that is made from both faulting and additional uplift. .

The seismic moment calculated from the estimated slip distribution (Fig. 3b) is $5.1 \times$ $10^{22} \mathrm{~N} \mathrm{~m}$ (Mw 9.1) by assuming the rigidity of $4 \times 10^{10} \mathrm{~N} \mathrm{~m}^{-2}$. The inferred slip distribution and inferred additional uplift generated initial sea surface deformation with a distinctive short wavelength and high peak $(11 \mathrm{~m})$ near the trench $($ Fig. 3d). The calculated horizontal and vertical displacements are consistent with the observations (Fig. 5b). Comparison between the observed and simulated tsunami waveforms from the source model with additional uplift 
is shown in Fig. 7. Observed tsunami waveforms and crustal deformation data are explained well by the result from the source model with additional uplift.

To evaluate the fitness between simulated and observed data from both source models, the root mean square (RMS) of the residual between simulated and observed data from each of source model is calculated. The RMS for the tsunami waveforms and crustal deformation from the results of the source model with additional uplift are $31.1 \mathrm{~cm}$ and $11.9 \mathrm{~cm}$, respectively. These are smaller than those calculated from the results of the source model without additional uplift, which are $33.3 \mathrm{~cm}$ for tsunami waveforms and $12.0 \mathrm{~cm}$ for crustal deformation. Standard error of each slip distribution is calculated by using Jackknife technique. The maximum error for the slip distribution without additional uplift is $\pm 6.1 \mathrm{~m}$, which is relatively small (Fig. 4a). The slip distribution with additional uplift is improved with smaller error than that for the slip distribution without additional uplift (Fig. $4 \mathbf{b b})$. These suggest that the additional uplift as the same as the 1896 Sanriku tsunami earthquake might occur during the 2011 great Tohoku earthquake because the 2011 Tohoku earthquake also ruptured the plate interface near the Japan Trench.

To analyze the effect of additional uplift near the trench on tsunami generation, the tsunami waveforms generated by the coseismic vertical deformation and those generated by the additional uplift due to the coseismic horizontal deformation are simulated separately. Then we integrate the first cycle of the generated tsunami waveforms at each station. The tsunami waveforms generated from the additional uplift at all stations range from $10 \%$ to $30 \%$ of the combined tsunami waveforms from both coseismic vertical deformation and additional uplift.

The seafloor crustal deformation data strongly constrains the slip distribution because 
deformation data in addition to tsunami waveforms to estimate a slip distribution, the fit to tsunami waveforms from our result is slightly worse than those from results that used only tsunami waveforms (e.g. Fujii et al., 2011; Saito et al., 2011). The misfit from our result is more apparent at DART21418, whereas slip distributions estimated by tsunami inversion studies (e.g. Fujii et al., 2011; Saito et al., 2011) can explain well the tsunami waveforms at DART21418. Saito et al. (2011) also suggest that dispersive tsunami is recorded at DART21418.

Ito et al. (2011) observed seafloor horizontal and vertical displacements at three stations (GJT3, TJT1, and TJT2) near the Japan Trench, and estimated a localized slip amount of $80 \mathrm{~m}$ near the trench to explain the observed displacements. The calculated vertical displacements of around 5.5 and $4.5 \mathrm{~m}$ from our slip distributions are very close to the observations of $5( \pm 2) \mathrm{m}$ and $5( \pm 0.5) \mathrm{m}$ at GTJ3 and TJT1, respectively. While the calculated horizontal displacements of 30-34 m from our slip distributions are smaller than the observations of $31 \pm 1 \mathrm{~m}, 58 \pm 20 \mathrm{~m}$, and $74 \pm 20 \mathrm{~m}$ at the three stations. The discrepancies may be explained by the difference of dip angle used in the two studies (i.e. this study dip is $5^{\circ}$ and in Ito et al. (2011) dip is $3^{\circ}$ ). The misfits may be reduced by further study of source models for this event that use a smaller subfault size and synthetic tsunami waveforms solved with dispersive tsunami equations.

\section{Conclusions}

In this study, joint inversion is performed using tsunami waveforms, GPS data and seafloor deformation data to study the source model of the 2011 earthquake. The earthquake ruptured the plate interface from the hypocenter all the way to the trench with large slip amounts up to $41 \mathrm{~m}$ on the shallowest subfaults. Total seismic moment calculated from 
estimated slip distributions with and without additional uplift are 5.1 and $5.5 \times 10^{22} \mathrm{~N} \mathrm{~m}(\mathrm{Mw}$ 9.1), respectively, which are consistent with that estimated by GCMT $\left(5.3 \times 10^{22} \mathrm{~N} \mathrm{~m}\right)$.

The large maximum slip is strongly constrained by the seafloor crustal deformation data near the epicenter. The tsunami waveforms data at offshore stations near the source area strongly constrain the generated initial sea surface deformation. These emphasize the importance of seafloor monitoring and offshore sea level observation to accurately estimate the slip distribution near the trench of interplate earthquakes in the subduction zone.

We indicate that not only coseismic vertical deformation but also additional uplift near the trench as suggested for the 1896 Sanriku tsunami earthquake may contribute the large tsunami near the seismic source of the 2011 Tohoku earthquake.

\section{Acknowledgements}

GPS buoy data are provided by MILT and PARI. KPG1 and KPG2 pressure gauge data are provided by JAMSTEC. TM1 and TM2 pressure gauge data are provided by Tohoku University and University of Tokyo. DART buoy data are downloaded from NOAA's website. Erimo and Mori tide gauge data are provided by JMA. Katsuura and Ito tide gauge data are downloaded from GSI's website. Preliminary GPS time series provided by the ARIA team at JPL and Caltech, all original GEONET RINEX data provided to Caltech by the Geospatial Information Authority (GSI) of Japan. Seafloor crustal deformation data are provided by Japan Coast Guard. We thank Peter M. Shearer and two anonymous reviewers for their constructive comments.

\section{References}

Akaike, H., 1980. Likelihood and the Bayes procedure, in: J. M. Bernando et al. (Eds.), Bayesian Statistics. Univ. Press, Valencia, Spain, pp. 143-166. 
Fritz, H. M., Phillips, D. A., Okayasu, A., Shimozono, T., Liu, H., Mohammed, F., Skanavis, measurements from survivor videos at Kesennuma Bay using LiDAR, Geophys. Res. Lett., 39, L00G23, doi:10.1029/2011GL050686.

Fujii, Y., and Satake, K., 2008, Tsunami sources of the November 2006 and January 2007 great Kuril earthquakes, Bull. Seismol. Soc. Am. 98, 1559-1571.

Fujii, Y., Satake, K., Sakai, S-I., Shinohara, M., Kanazawa, T., 2011. Tsunami source of the 2011 off the Pacific coast of Tohoku, Japan earthquake. Earth Planets Space 63, 815-820.

Gusman, A. R., Tanioka, Y., Kobayashi, T., Latief, H., Pandoe, W., 2010. Slip distribution of the 2007 Bengkulu earthquake inferred from tsunami waveforms and InSAR data. J. Geophys. Res. 115, B12316, doi:10.1029/2010JB007565. Fujimoto, H., 2011. Frontal wedge deformation near the source region of the 2011 TohokuOki earthquake. Geoph. Res. Lett. 38, L00G05, doi:10.1029/2011GL048355.

Johnson, J. M., 1998. Heterogeneous coupling along Alaska-Aleutians as inferred from tsunami, seismic, and geodetic inversions. Adv. Geophys. 39, 1-116. Institute 41, 535-571. earthquake of 1933. Phys. Earth Planet. Inter. 4, 289-300. 
338

339

340

341

342

343

344

345

346

347

348

349

350

351

352

353

354

355

356

357

358

359

Kanamori, H., 1972. Mechanism of tsunami earthquakes. Phys. Earth Planet. Inter. 6, 346359.

Lay, T., Ammon, C. J., Kanamori, H., Xue, L., Kim, M. J., 2011. Possible large near-trench slip during the $2011 \mathrm{Mw} 9.0$ off the Pacific coast of Tohoku earthquake. Earth Planets Space $63,687-692$

Lawson, C. L., Hanson, B. J., 1974. Solving least squares problems, Prentice Hall Inc., Englewood Cliffs, New Jersey, US.

Maeda T., Furumura, T., Sakai, S., Shinohara, M., 2011. Significant tsunami observed at the ocean-bottom pressure gauges at 2011 the Pacific Coast of Tohoku Earthquake. Earth Planets Space 63, 803-808.

Minoura, K., Imamura, F., Sugawara, D., Kono, Y., Iwashita, T., 2001. The 869 Jogan tsunami deposit and recurrence interval of large-scale tsunami on the Pacific coast of northeast Japan. Journal of Natural Disaster Science 23-2, 83-88.

Miura, S., Iinuma, T., Yui, S., Uchida, N., Sato, T., Tachibana, K., Hasegawa A., 2006. Coand postseismic slip associated with the 2005 Miyagi-oki earthquake (M7.2) as inferred from GPS data. Earth Planets Space 58, 1567-1572.

Mori, N., Takahashi, T. and the 2011 Tohoku Earthquake Tsunami Joint Survey Group (2012). Nationwide post event survey and analysis of the 2011 Tohoku earthquake tsunami. Coastal Eng. J., 54(1), 1250001, doi: 10.1142/S0578563412500015.

Namegaya, Y., Satake, K., Yamaki, S., 2010. Numerical simulation of the AD 896 Jogan tsunami in Ishinomaki and Sendai plains and Ukedo river-mouth lowland. Annual Report on Active Fault and Paleoearthquake Researches 10, 1-21. (in Japanese) 
360

361

362

363

364

365

366

367

368

369

370

371

372

373

374

375

376

377

378

379

380

381

Okada, Y., 1985. Surface deformation due to shear and tensile faults in half-space. Bull. Seism. Soc. Am. 75-4, 1135-1154.

Ozawa S., Nishimura, T., Suito, H., Kobayashi, T., Tobita, M., Imakiire, T., 2011. Coseismic and postseismic slip of the 2011 magnitude-9 Tohoku-Oki earthquake, Nature 475, 373-376, doi:10.1038/nature10227.

Sagiya, T., Miyazaki, S., Tada, T., 2000. Continuous GPS array and present-day crustal deformation of Japan, Pure Appl. Geophys. 157, 2303-2322.

Saito, T., Ito, Y., Inazu, D., and Hino, R., 2011. Tsunami source of the 2011 Tohoku-Oki earthquake, Japan: Inversion analysis based on dispersive tsunami simulations, Geophys. Res. Lett. 38, L00G19, doi:10.1029/2011GL049089.

Satake, K., 2002. Tsunamis, in: W.H.K. Lee et al. (Eds.), International Handbook of Earthquake and Engineering Seismology 81A. Academic Press, China, pp. 437-451.

Sato, M., Ishikawa, T., Ujihara, N., Yoshida, S., Fujita, M., Mochizuki, M., Asada, A., 2011. Displacement above the hypocenter of the 2011 Tohoku earthquake. Science, 1-2, doi:10.1126/science.1207401.

Seno, T., 2000. The 21 September, 1999 Chichi earthquake in Taiwan: implications for tsunami earthquakes. Terr. Atmos. Ocean Sci. 11, 701-708.

Seno, T.,Hirata, K., 2007. Did the 2004 Sumatra-Andaman earthquake involve a component of tsunami earthquakes? Bull. Seism. Soc. Am. 97-1A, S296-S306, doi:10.1785/0120050615.

Shimozono, T., Sato, S., Okayasu, A., Tajima, Y., Fritz, H.M., Liu, H., Takagawa, T. (2012). Propagation and Inundation Characteristics of the 2011 Tohoku Tsunami on the Central Sanriku Coast, Coastal Eng. J., 54(1), 1250004, doi:10.1142/S0578563412500040. 
382

383

384

385

386

387

388

389

390

391

392

393

394

395

396

397

398

399

400

401

402

403

Synolakis, C. E., Bernard, E. N., Titov, V. V., Kanoglu, U., Gonzalez, F. I., 2008. Validation and verification of tsunami numerical models. Pure Appl. Geophys. 165, 2197-2228, doi:10.1007/s00024-004-0427-y.

Tanioka, Y., Satake, K., 1996a. Fault parameters of the 1896 Sanriku tsunami earthquake estimated from tsunami numerical modeling. Geophys. Res. Lett. 23-13, 1549-1552.

Tanioka, Y., Satake, K., 1996b. Tsunami generation by horizontal displacement of ocean bottom, Geophys. Res. Lett. 23 (8), 861-864, doi:10.1029/96GL00736.

Tanioka, Y., Seno, T., 2001. Sediment effect on tsunami generation of the 1896 Sanriku tsunami earthquake. Geophys. Res. Lett. 28-17, 3389-3392.

Tanioka, Y., Hasegawa, Y., and Kuwayama, T., 2008, Tsunami waveform analyses of the 2006 underthrust and 2007 outer-rise Kurile earthquakes, Advances in Geosciences 14, 129134.

Tichelarr, B. W., and Ruff, L. J., 1989. How good are our best models? Jackknifing, bootstrapping, and earthquake depth, Eos Trans. AGU. 70, 593, 605-606.

Tsuji, T., Ito, Y., Kido, M., Osada, Y., Fujimoto, H., Ashi, J., Kinoshita, M., and Matsuoka, T., 2011. Potential tsunamigenic faults of the 2011 off the Pacific coast of Tohoku earthquake. Earth Planets and Space 63, 831-834.

Tsuji, Y., 2003. Special characteristic of the 1611 Keichou Sanriku tsunami. Chikyu Monthly 25-5, 374-381. (in Japanese).

Yamanaka, Y., Kikuchi, M., 2004. Asperity map along the subduction zone in northeastern Japan inferred from regional seismic data. J. Geophys. Res. 109, B07307, doi:10.1029/2003JB002683. 
404 Yoshida, Y., Ueno, H., Muto, D., Aoki, S., 2011. Source process of the 2011 off the Pacific 405 Coast of Tohoku earthquake with the combination of teleseismic and strong motion data. 406 Earth Planets Space 58, 1-5. 


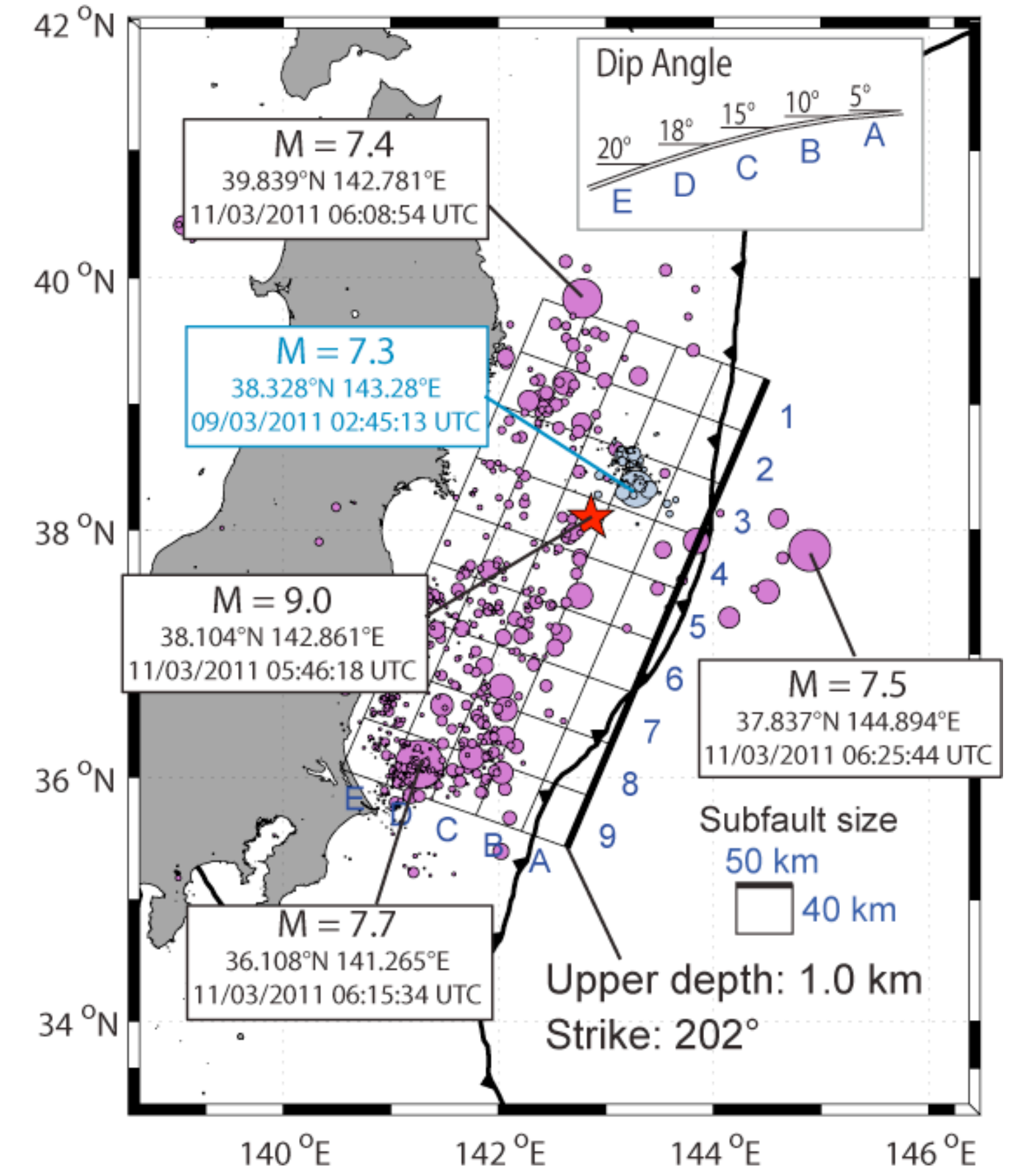

410 Fig. 1. Map of the 2011 Tohoku earthquake. Red star represents the epicenter of the 411 mainshock, gray circles represent foreshocks and purple circles represent aftershocks and 412 extensional faulting events in the outer-rise. 


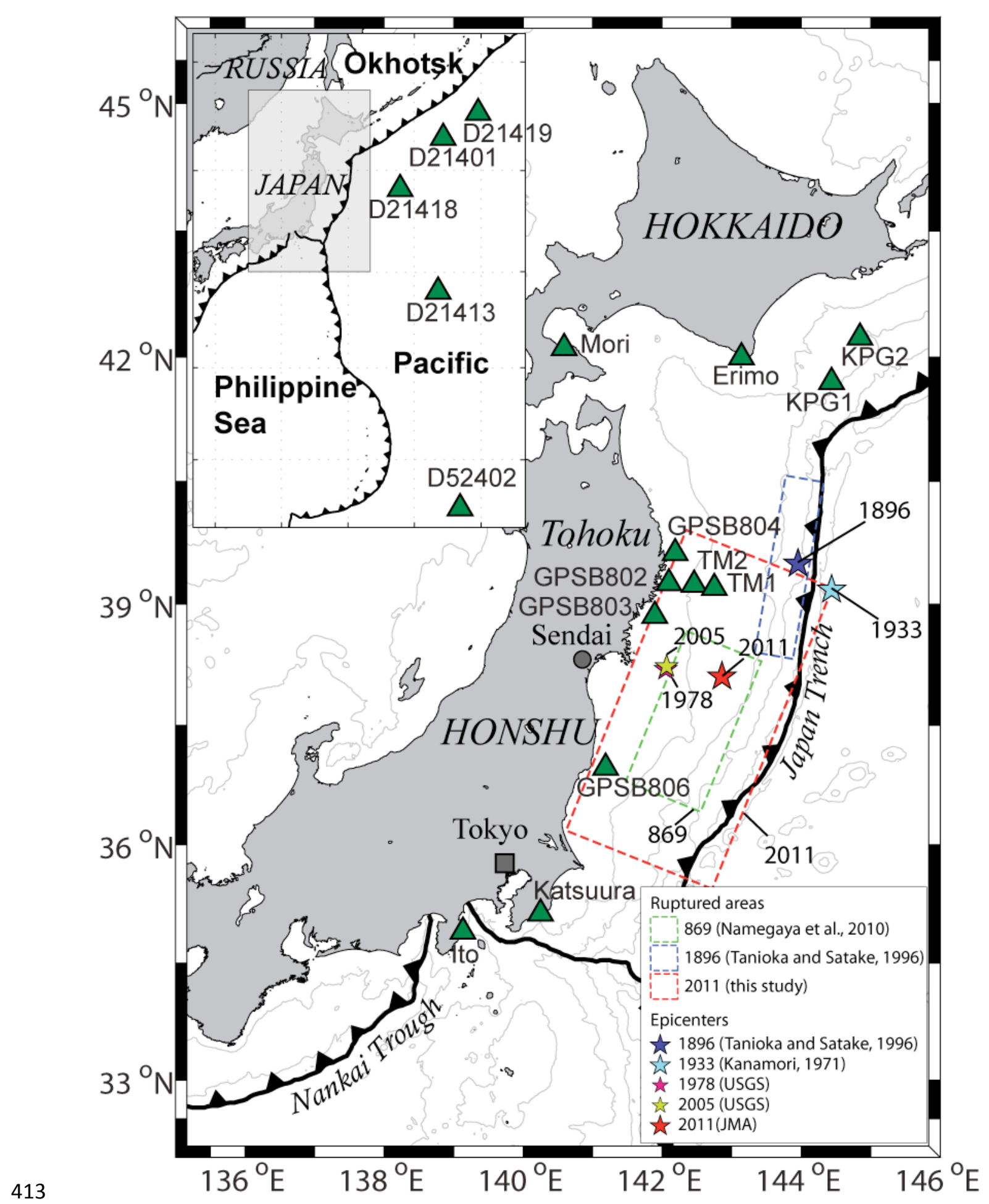

414 Fig. 2. Map of sea level observation stations (green triangles). Stars represent epicenters and 415 rectangles represent ruptured areas. 
a)

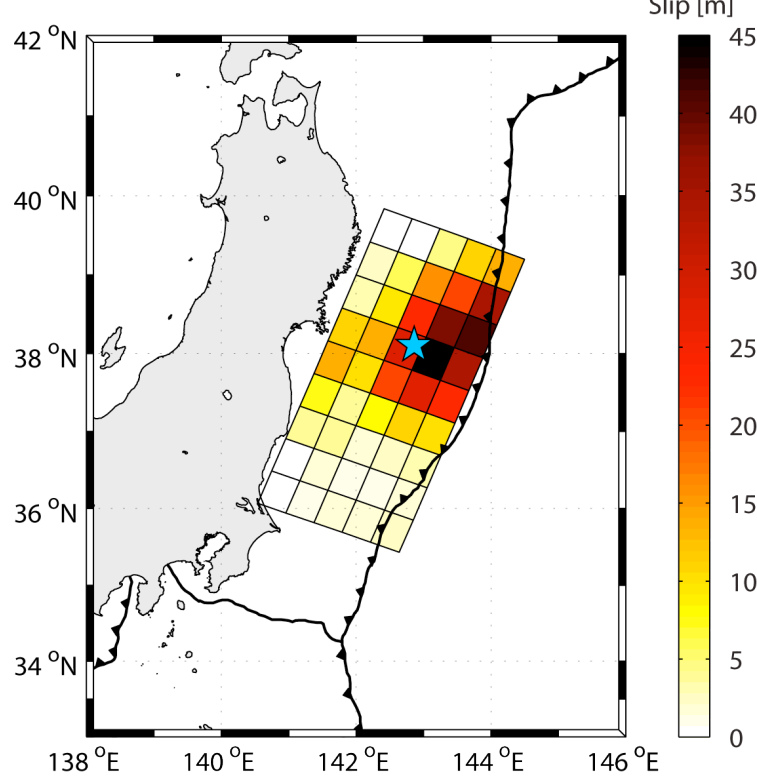

c)

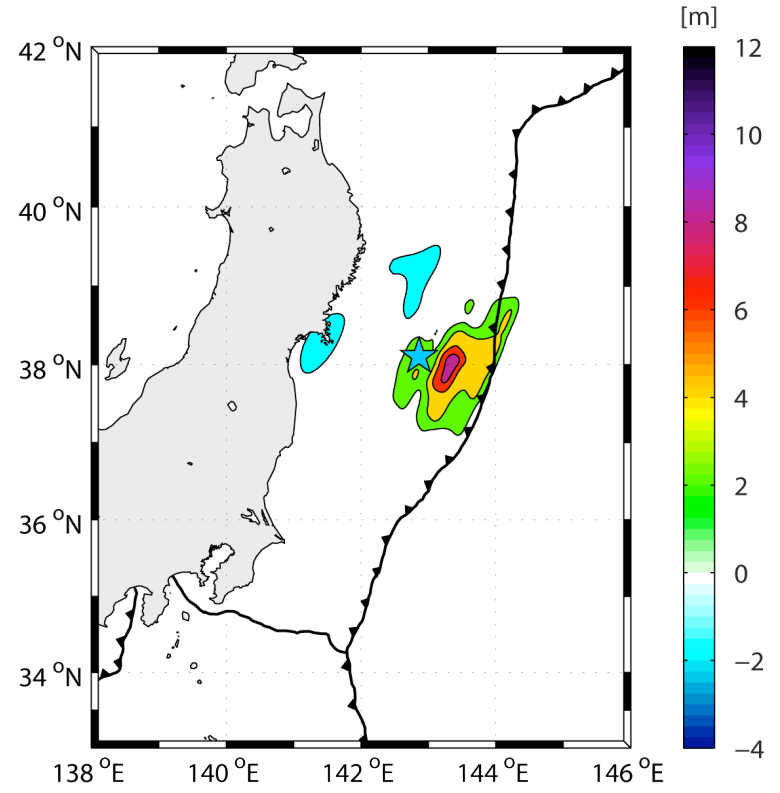

b)

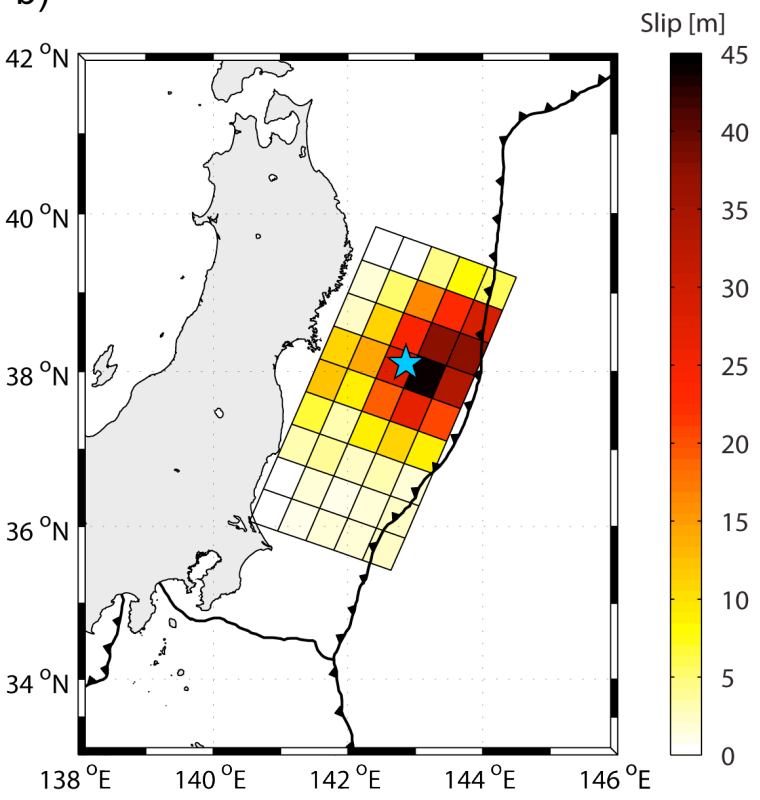

d)

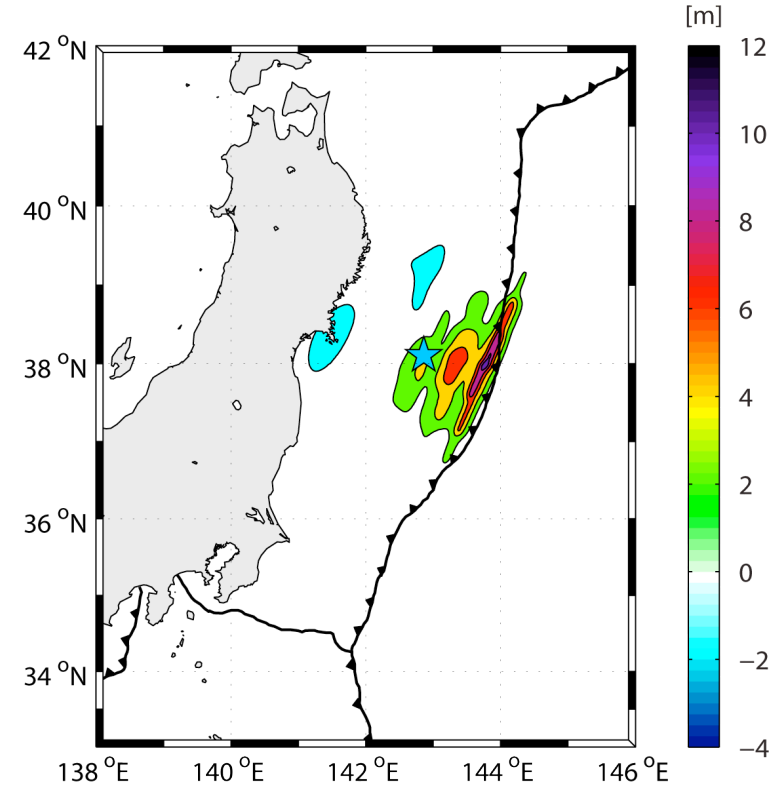

Fig. 3. a) Slip distribution of the 2011 Tohoku earthquake estimated from tsunami waveforms

419 and crustal deformation data and b) estimated slip distribution of the 2011 Tohoku

420 earthquake when the green's function is constructed from both faulting and additional uplift.

c) Sea surface deformation generated from the slip distribution of Fig. 3a. d) Sea surface deformation generated from the slip distribution of Fig. 3b and the inferred additional uplift. 
No Additional Uplift

a) Slip distribution along strike
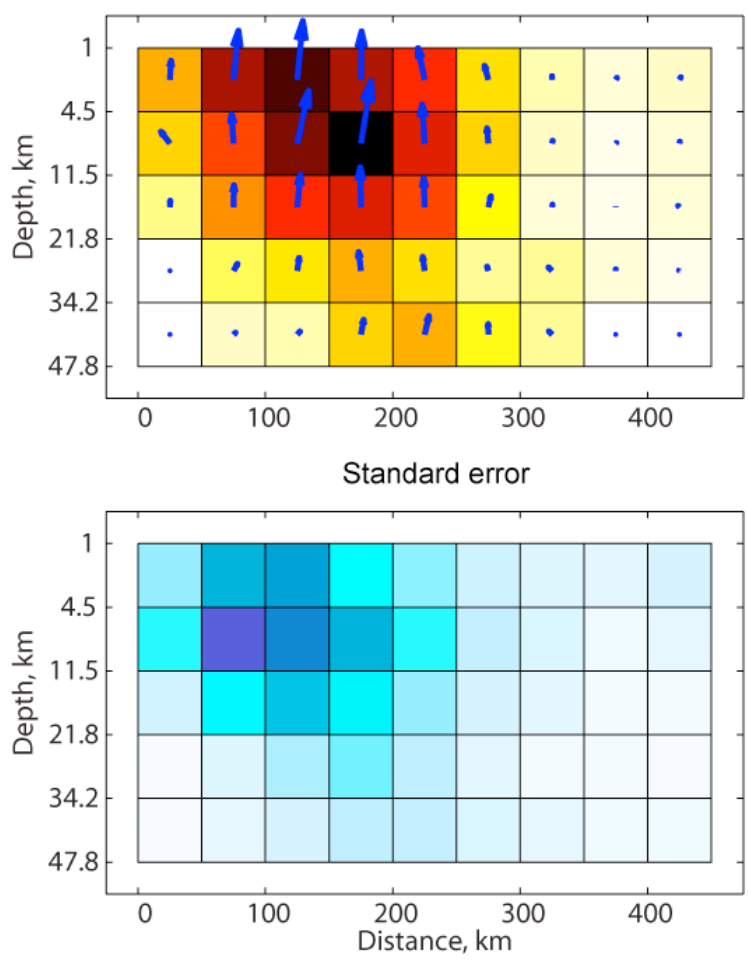

With Additional Uplift

b) Slip distribution along strike

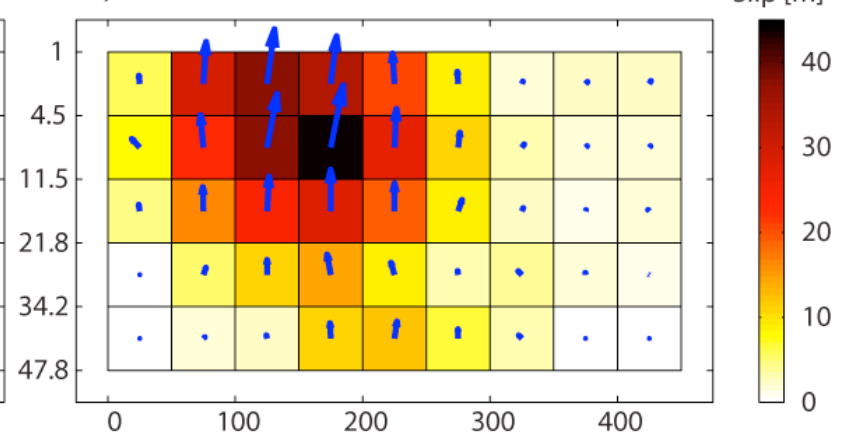

Error $\pm[\mathrm{m}]$

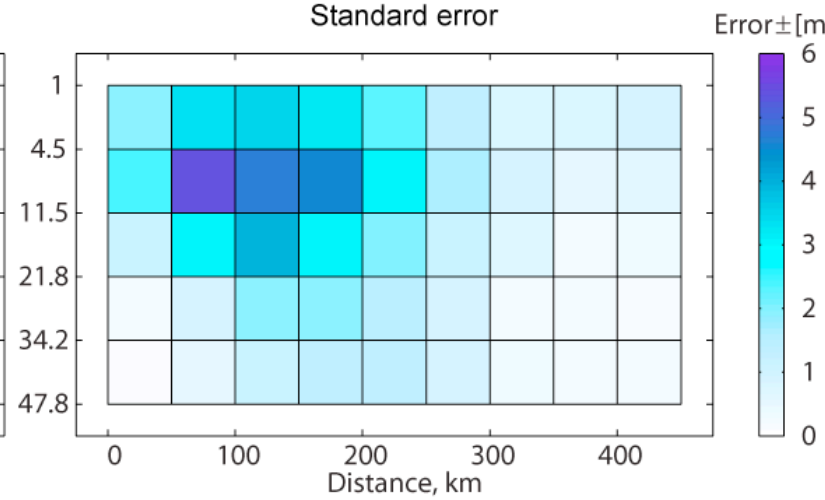

424

Fig. 4. Slip distribution and its “delete-half” Jackknife standard deviation (standard error). a)

426 Slip distribution along strike of the 2011 Tohoku earthquake estimated from tsunami

427 waveforms and crustal deformation data. b) Estimated slip distribution along strike of the

4282011 Tohoku earthquake when the green's function is constructed from both faulting and

429 additional uplift. Blue arrow represents the inferred rake angle of each subfault. 
a)

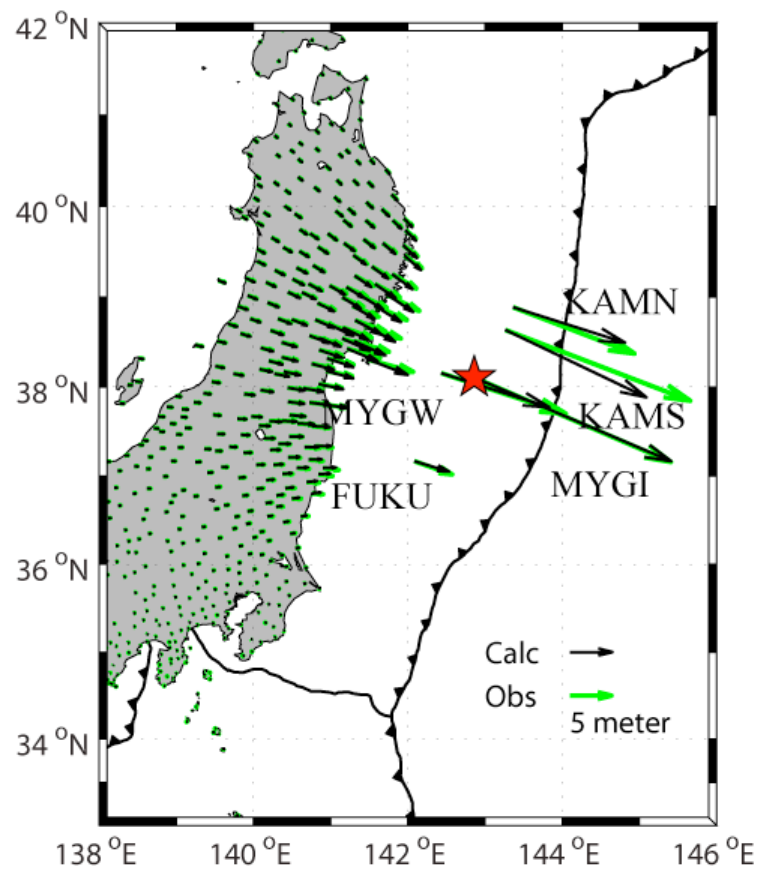

Vertical displacements

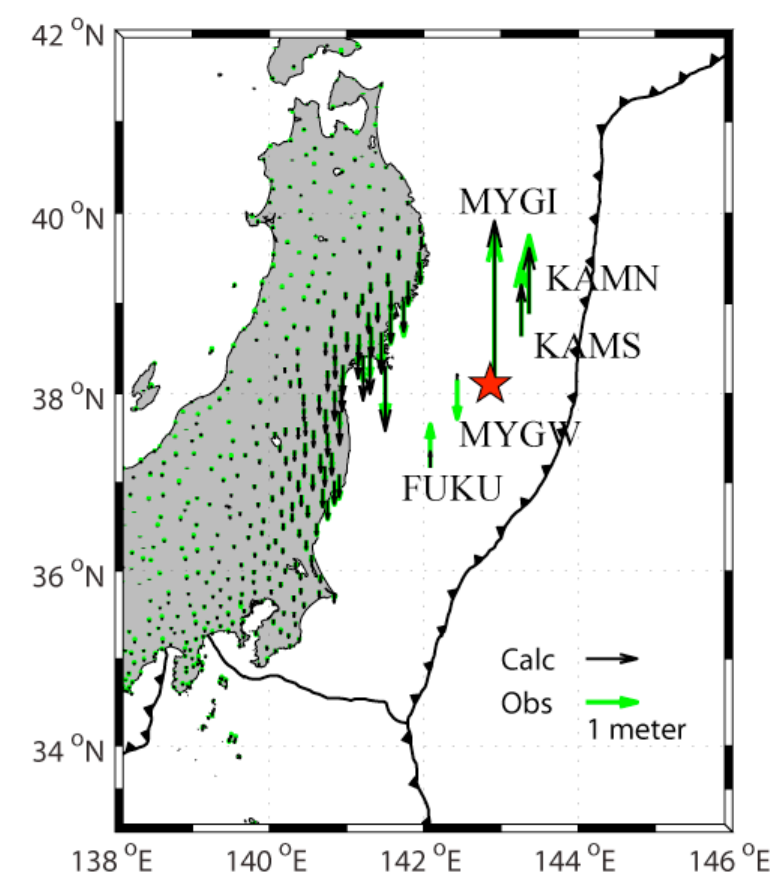

With Additional Uplift

b) Horizontal displacements

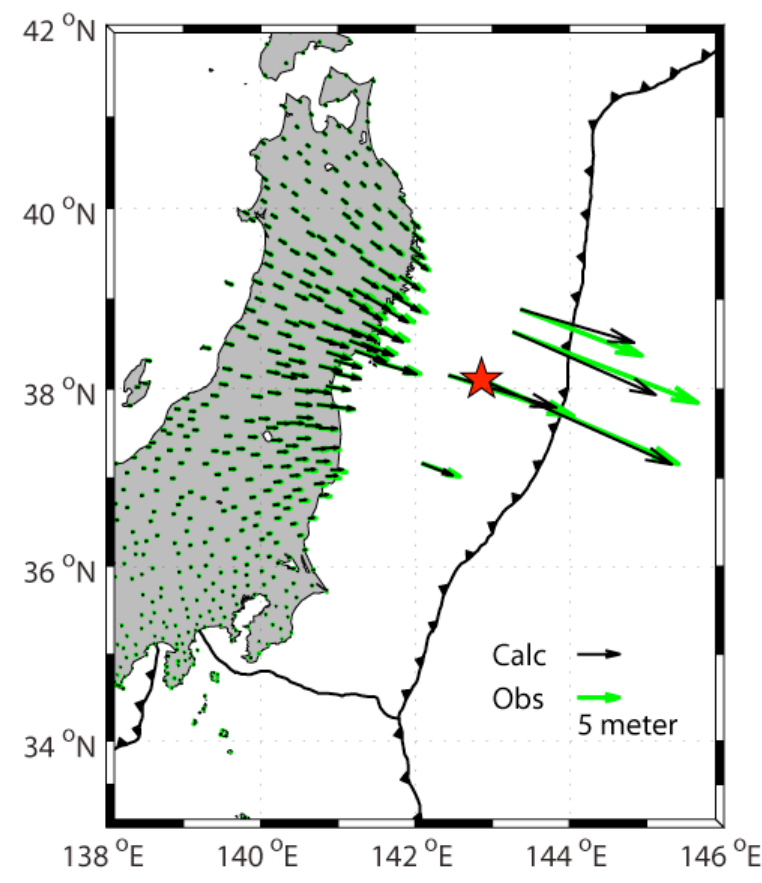

Vertical displacements

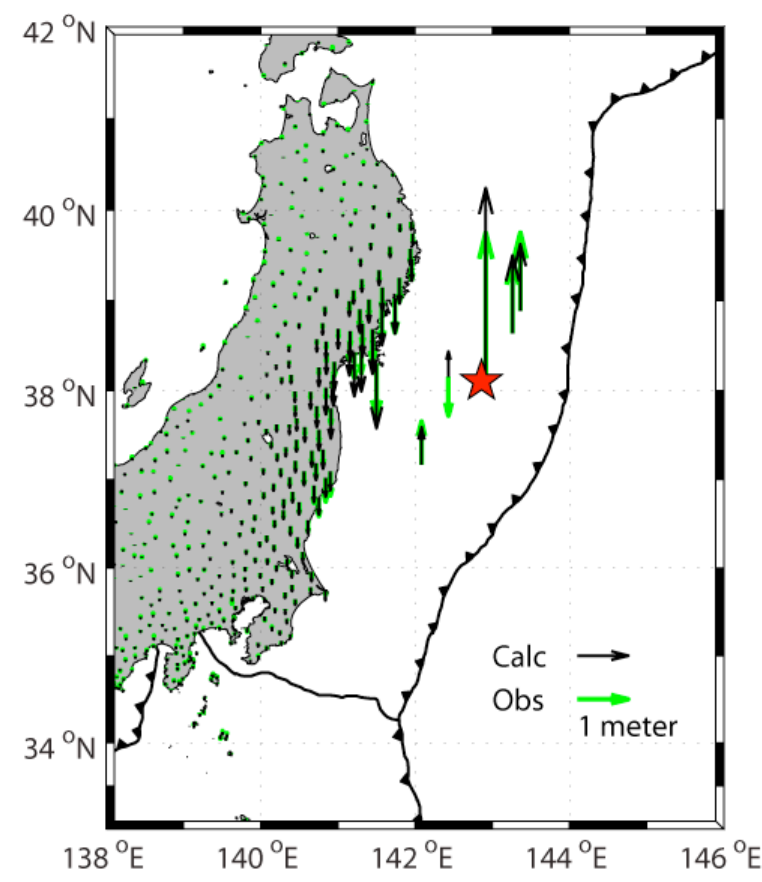

431 Fig. 5. Comparison between observed (green arrows) and calculated (black arrows) coseismic

432 displacements. a) Horizontal and vertical displacements calculated from the slip distribution

433 of Fig. 3a. b) Horizontal and vertical displacements calculated from the slip distribution of 434 Fig. 3b. 

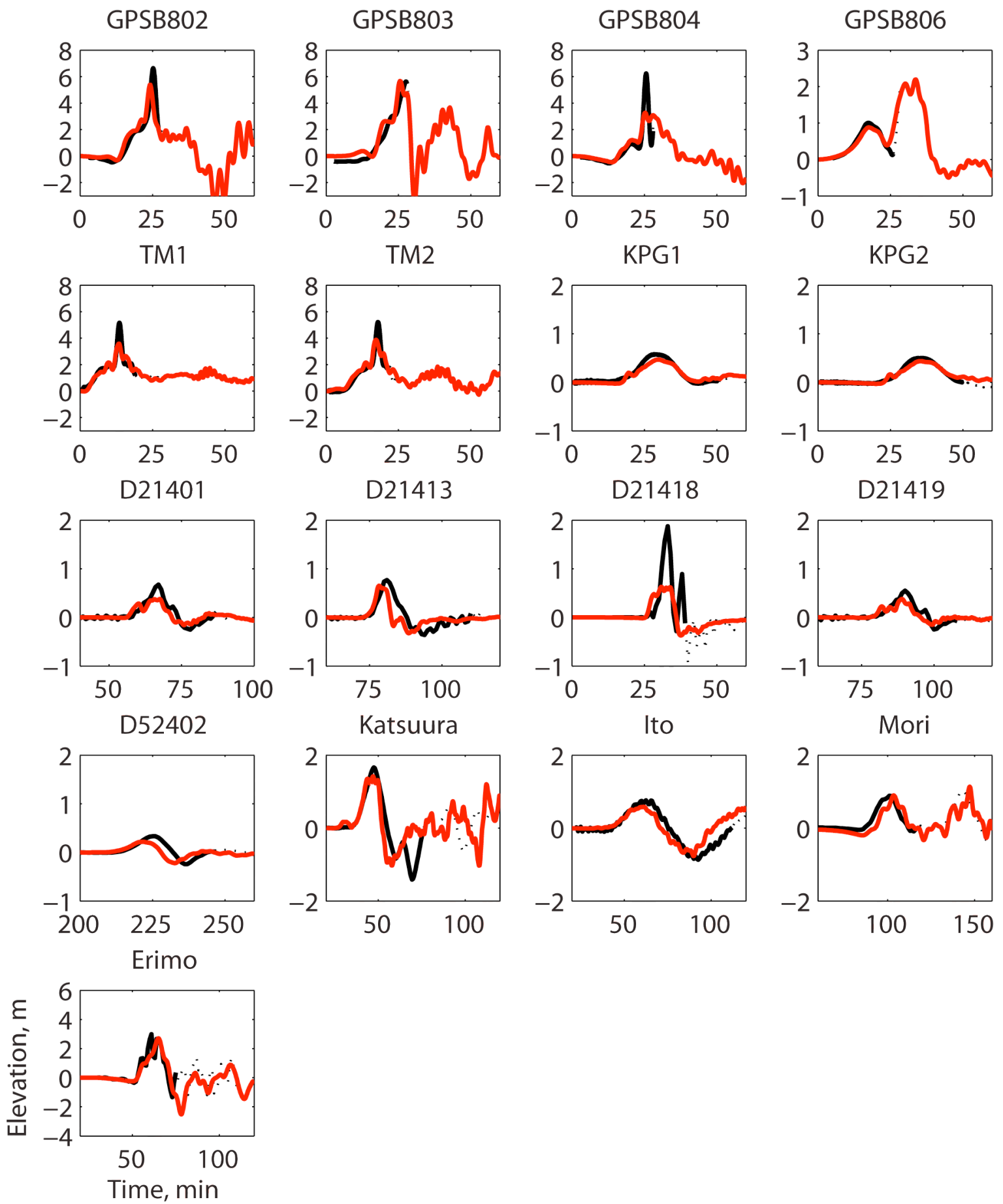

Time, $\min$

436 Fig. 6. Observed and simulated tsunami waveforms from the slip distribution of Fig. 3a. Red

437 lines represent the simulated tsunami waveforms, black lines represent the observed tsunami 438 waveforms that are used in the inversion, and black dashed lines are the observed tsunami 439 waveforms. 

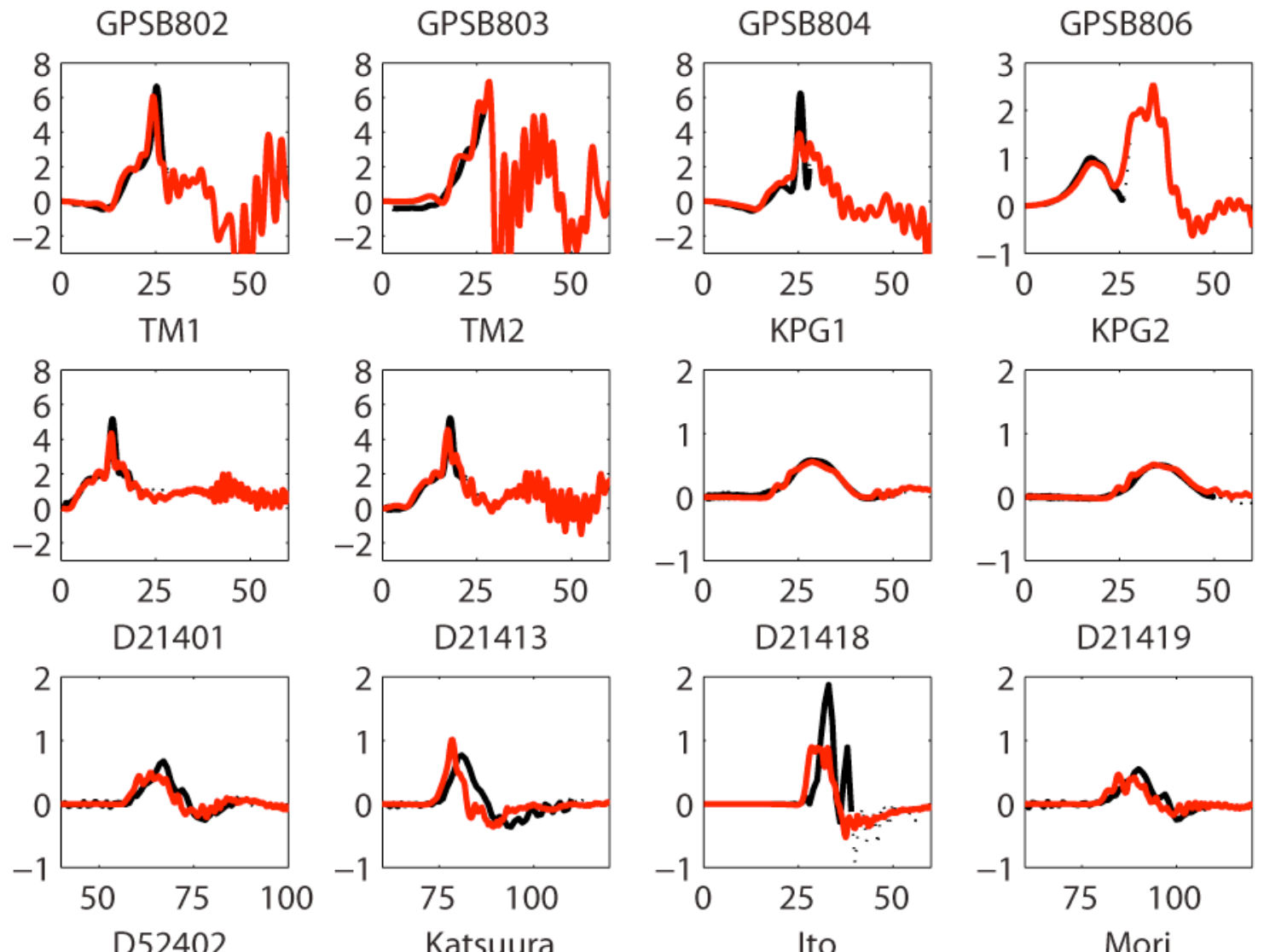

D21419
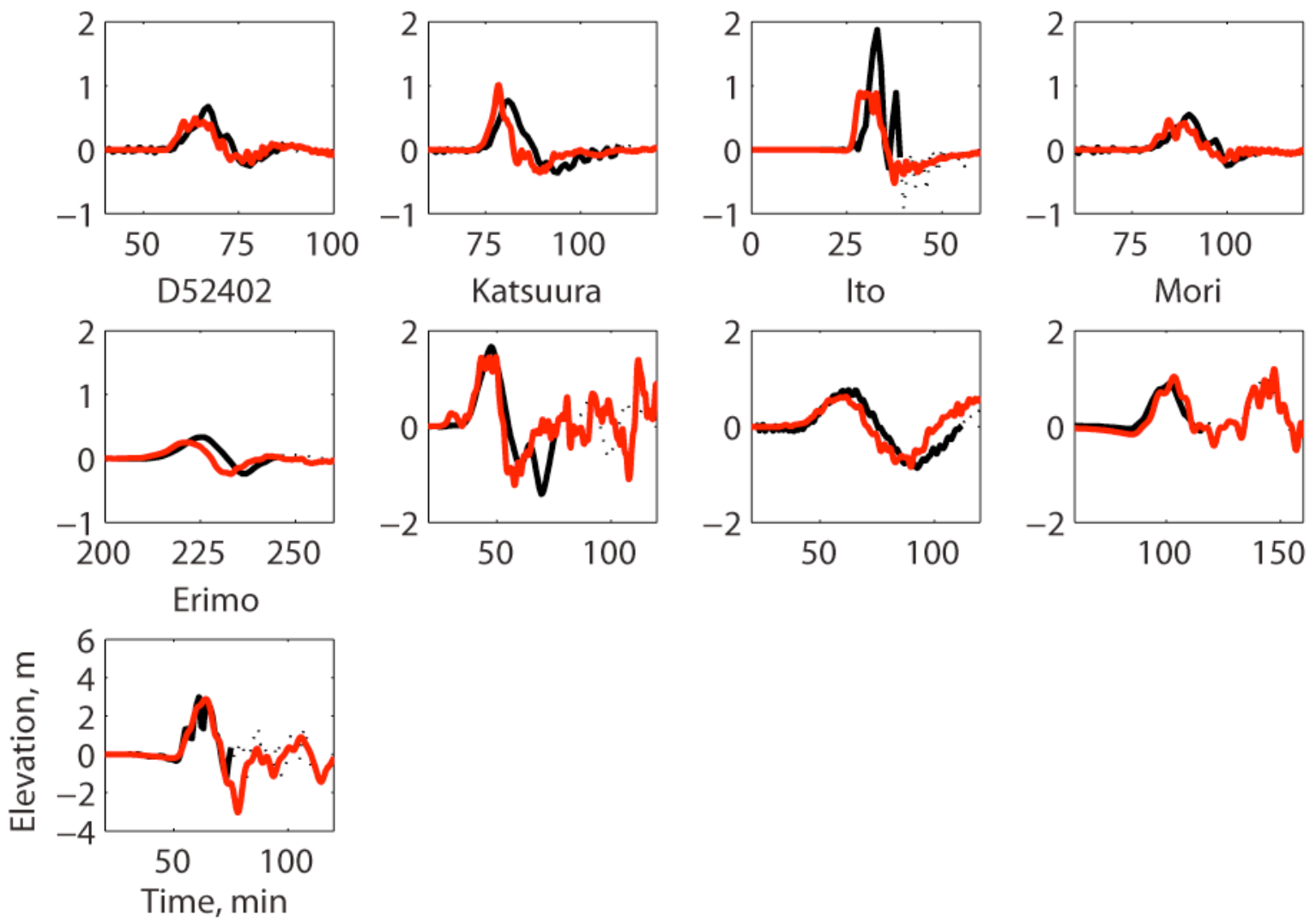

Time, min

442 Fig. 7. Observed and simulated tsunami waveforms from source model with the additional 443 uplift. Red lines represent the simulated tsunami waveforms, black lines represent the 444 observed tsunami waveforms that are used in the inversion, and black dashed lines are the 445 observed tsunami waveforms. 
448 Table S1. List of bottom-pressure, GPS buoy, and tide gauge stations.

\begin{tabular}{|c|c|c|c|c|c|c|c|}
\hline No & Name & $\begin{array}{l}\text { Longitude } \\
\left({ }^{\circ} \mathrm{E}\right)\end{array}$ & $\begin{array}{l}\text { Latitude } \\
\left({ }^{\circ} \mathrm{N}\right)\end{array}$ & Type & Authority & $\begin{array}{l}\text { Maximum } \\
\text { amplitude } \\
(\mathrm{cm})\end{array}$ & $\begin{array}{l}\text { Arrival time } \\
\text { in minutes } \\
\text { after time } \\
\text { origin }\end{array}$ \\
\hline 1. & $\begin{array}{l}\text { DART } \\
21401\end{array}$ & 152.583 & 42.617 & $\begin{array}{l}\text { Bottom- } \\
\text { pressure }\end{array}$ & $\begin{array}{l}\text { RFERHRI } \\
\text { and NOAA }\end{array}$ & 67 & 67 \\
\hline 2. & $\begin{array}{l}\text { DART } \\
21413\end{array}$ & 152.123 & 30.528 & $\begin{array}{l}\text { Bottom- } \\
\text { pressure }\end{array}$ & NOAA & 77 & 81 \\
\hline 3. & $\begin{array}{l}\text { DART } \\
21418\end{array}$ & 148.698 & 38.718 & $\begin{array}{l}\text { Bottom- } \\
\text { pressure }\end{array}$ & NOAA & 187 & 33 \\
\hline 4. & $\begin{array}{l}\text { DART } \\
21419\end{array}$ & 155.735 & 44.455 & $\begin{array}{l}\text { Bottom- } \\
\text { pressure }\end{array}$ & NOAA & 55 & 90 \\
\hline 5. & $\begin{array}{l}\text { DART } \\
52402\end{array}$ & 154.111 & 11.882 & $\begin{array}{l}\text { Bottom- } \\
\text { pressure }\end{array}$ & NOAA & 32 & 224 \\
\hline 6. & Erimo & 143.142 & 42.000 & Tide gauge & JMA & 298 & 61 \\
\hline 7. & Mori & 140.591 & 42.112 & Tide gauge & $\begin{array}{l}\text { MLIT and } \\
\text { PARI }\end{array}$ & 88 & 101 \\
\hline 8. & $\begin{array}{l}\text { Katsuur } \\
\text { a }\end{array}$ & 140.250 & 35.133 & Tide gauge & GSI & 166 & 47.5 \\
\hline 9. & Ito & 139.133 & 34.900 & Tide gauge & GSI & 76 & 62.5 \\
\hline 10. & KPG1 & 144.438 & 41.704 & $\begin{array}{l}\text { Bottom- } \\
\text { pressure }\end{array}$ & JAMSTEC & 58 & 28.3 \\
\hline 11. & KPG2 & 144.845 & 42.236 & $\begin{array}{l}\text { Bottom- } \\
\text { pressure }\end{array}$ & JAMSTEC & 50 & 35.5 \\
\hline 12. & TM1 & 142.750 & 39.200 & $\begin{array}{l}\text { Bottom- } \\
\text { pressure }\end{array}$ & $\begin{array}{l}\text { Tohoku } \\
\text { Univ and } \\
\text { Univ. of } \\
\text { Tokyo }\end{array}$ & 516 & 13.6 \\
\hline 13. & TM2 & 142.460 & 39.240 & $\begin{array}{l}\text { Bottom- } \\
\text { pressure }\end{array}$ & $\begin{array}{l}\text { Tohoku } \\
\text { Univ and }\end{array}$ & 521 & 17.9 \\
\hline
\end{tabular}




\begin{tabular}{|l|l|l|l|l|l|l|l|}
\hline & & & & & $\begin{array}{l}\text { Univ. of } \\
\text { Tokyo }\end{array}$ & \\
\hline 14. & $\begin{array}{l}\text { GPSB8 } \\
02\end{array}$ & 142.097 & 39.259 & GPS buoy & $\begin{array}{l}\text { MLIT and } \\
\text { PARI }\end{array}$ & 664 & 25.2 \\
\hline 15. & $\begin{array}{l}\text { GPSB8 } \\
04\end{array}$ & 142.187 & 39.627 & GPS buoy & $\begin{array}{l}\text { MLIT and } \\
\text { PARI }\end{array}$ & 623 & 25.6 \\
\hline 16. & $\begin{array}{l}\text { GPSB8 } \\
03\end{array}$ & 141.894 & 38.858 & GPS buoy & $\begin{array}{l}\text { MLIT and } \\
\text { PARI } 563\end{array}$ & 27.5 \\
\hline 17 & $\begin{array}{l}\text { GPSB8 } \\
06\end{array}$ & 141,1856 & 36.9714 & GPS buoy & $\begin{array}{l}\text { MLIT and } \\
\text { PARI } 100\end{array}$ & 17.45 \\
\hline
\end{tabular}

449 GSI: Geospatial Information Authority of Japan

450 JAMSTEC: Japan Agency for Marine-Earth Science and Technology

451 JMA: Japan Meteorological Agency

452 MLIT: Ministry of Land, Infrastructure, Transport, and Tourism

453 NOAA: National Oceanic and Atmospheric Administration

454 PARI: Port and Airport Research Institute 